\title{
ANALISIS VARIABEL-VARIABEL YANG MEMPENGARUHI MOTIVASI KERJA PADA KOPERASI PERSATUAN PEDAGANG KAKI LIMA YOGYAKARTA (KPPKLY)
}

\author{
FX.Suwarto \\ Fakultas Ekonomi Universitas Atma Jaya Yogyakarta \\ Emai:fx.suwarto@yahoo.com
}

\begin{abstract}
This research is conducted on Koperasi Persatuan Pedagang Kaki Lima Jogjakarta (PPKLJ). The objective of this research is to recognize and analyze: 1$)$ work motivation, (2) assesment tothe variable that influence to the work motivation, (3) both the significance and insignificance of the nine variable to the workmotivation, (4) variables which are the most significant to the workmotivation. Quistioner and interview are used to collect data on this research.there are independent variable $(\mathrm{X})$ Consisting of wage (X1), work place (X2), work equipment (X3), work attitute to the job (X4), the attitute to co-workers (X5) trust and responcibility (X6), the needs to develop the ability (X7), the needs to get the best performance (X8); and the dependent variable (Y), which is work motivation. SPS is used to analyze the data on this research. By calculating the data analysis, it is abtained that there are (1) high work motivation on the worker, (2) good worker assesment to variables that influent work motivation, (3) eight variables significantly influence work motivation, (4) the needs variables to get the best performance have the most significant influence to work motivation. The conclusion of the analysis result is that the eight variables exceedingly influence to the work it would be able to develop the worker work motivation, the manager is expected to concern of those eight variables. Particulary the variable of need to get best performance (X8), since it has the most significant influence, there fore the purpose of worker effort continiusly guaranteed.
\end{abstract}

Keywords: motivation, work motivation variables

Abstrak: Penelitian ini dilakukan pada Koperasi Persatuan Pedagang Kaki Lima Yogyakarta (KPPKLY). Tujuan dari penelitian ini adalah untuk mengetahui dan menganalisis: (1) motivasi kerja, (2) penilaian terhadap variabel-variabel yang mempengaruhi motivasi kerjanya, (3) signifikan dan tidaknya pengaruh kesembilan variabel terhadap motivasi kerja, (4) variabel yang mempunyai pengaruh paling signifikan terhadap motivasi kerja. Teknik pengumpulan data yang digunakan adalah menggunakan kuesioner dan interview. Dalam penelitian ini terdiri dari variabel independent (X) yaitu meliputi: upah (X.1), tempat kerja (X.2), peralatan kerja (X.3), sikap pekerja terhadap pekerjaannya (X.4), sikap antar teman sejawat (X.5), kepercayaan dan tanggung jawab (X.6), kebutuhan untuk meningkatkan kemampuan (X.7), kebutuhan untuk berprestasi (X.8) dan variabel dependen (Y) yaitu motivasi kerja. Analisis data dalam penelitian ini menggunakan SPSS. Dari hasil perhitungan analisis data didapat bahwa (1) motivasi kerja pekerja adalah kuat, (2) penilaian pekerja terhadap variabel-variabel yang mempengaruhi motivasi kerja adalah baik, (3) kedelapan variabel secara bersama-sama berpengaruh secara signifikan terhadap motivasi kerja, (4) variabel kebutuhan untuk berpresatasi memiliki pengaruh paling signifikan terhadap motivasi kerja. Dari hasil analisis dapat 
diambil kesimpulan bahwa kedelapan variabel sangat berpengaruh terhadap motivasi kerja, agar dapat meningkatkan motivasi kerja pekerja, para pengelola diharapkan selalu memperhatikan kedelapan variabel tersebut, terutama variabel kebutuhan untuk berprestasi (X8) karena paling signifikan pengaruhnya, dengan demikian tujuan usahanya mempunyai keberlanjutan dapat terjamin.

Kata kunci: motivasi, variabel-variabel motivasi kerja.

\section{PENDAHULUAN}

Dalam era globalisasi saat ini, dunia usaha dituntut untuk tidak hanya mampu menciptakan peluang yang mendatangkan keuntungan bagi usahanya melainkan juga mampu menerapkan manajemen usaha yang baik.Setiap kegiatan usaha tentu ingin mancapai tujuan. Untuk mencapai tujuan tersebut, peranan manusia/SDM yang terlibat didalamnya sangat penting. Untuk menggerakkan manusia agar sesuai dengan yang dikehendaki kegiatan usaha, maka harus dipahami motivasi kerja para pekerja yang bekerja didalam kegiatan usaha tersebut, karena motivasi kerja inilah yang menentukan perilaku orang-orang untuk bekerja, atau dengan kata lain perilaku merupakan cerminan yang paling sederhana dari motivasi. Salah satu definisi motivasi kerja adalah kesediaan untuk mengeluarkan tingkat upaya yang tinggi ke arah tujuan organisasi, yang dikondisikan oleh kemampuan upaya itu untuk memenuhi sesuatu kebutuhan individual (Stephen P. Robbins:2009). Kekuatan psikologis yang memotivasi seseorang dapat berasal dari dalam individu itu sendiri, atau dapat juga berasal dari faktor-faktor yang berasal dari luar individu. Seseorang yang termotivasi melakukan sesuatu karena kesadaran dan keinginan sendiri dikatakan sebagai orang yang termotivasi secara intrinsik (sumber motivasinya disebut motivasi intrinsik). Sedangkan individu yang termotivasi oleh perolehan penghargaan, keuntungan material tertentu atau menghindari hukuman, dikatakan sebagai orang termotivasi secara ekstrinsik (sumber motivasinya disebut motivasi ekstrinsik). Seseorang dapat saja termotivasi secara intrinsik atau ekstrinsik atau keduanya. Individu yang memiliki motivasi intrinsik diyakini akan memiliki tingkat usaha yang lebih besar dan daya juang yang lebih tinggi dalam menghadapi hambatan. Namun dalam kasus pengelolaan kegiatan usaha, sangat sulit memperoleh dan mengendalikan individu yang termotivasi intrinsik. Pengelolaan kegiatan usaha sering kali hanya dapat menciptakan motivasi ekstrinsik, yaitu melalui program penghargaan kinerja yang 'menarik', imbalan material yang kompetitif, sanksi yang berat, lingkungan kerja yang nyaman, jenjang karir yang menjanjikan, pendidikan berkelanjutan.

Beberapa teori dikembangkan untuk menjelaskan faktor-faktor yang memotivasi seseorang, kenapa dan bagaimana proses seseorang termotivasi, serta bagaimanakah seseorang mempertahankan tingkat motivasinya. Secara garis besar teori-teori tersebut terbagi menjadi tiga macam kategori utama, yaitu: Teori isi, membantu para pengelolaan kegiatan usaha memahami "kebutuhan" manusia dan bagaimana para pekerja yang memiliki kebutuhan berbeda-beda dapat memberikan tanggapan kepada situasi pekerja yang berlainan. Teori proses, membantu para pengelolaan kegiatan usaha memahami bagaimana para pekerja memberikan makna terhadap penghargaan dan kesempatan kerja yang tersedia guna meraihnya. Teori penguatan, membantu para pengelolaan kegiatan usaha memahami bagaimana perilaku para pekerja akan terpengaruh oleh konsekuensikonsekuensi lingkungannya. Setiap kegiatan usaha mempunyai sistem manajemen yang 
berbeda dan berubah sejalan dengan perkembangan. Begitu pula dengan pada Koperasi Persatuan Pedagang Kaki Lima Yogyakarta (KPPKLY) sebagai salah satu kegiatan usaha ekonomi kerakyatan, memiliki pekerja, memiliki tujuan, keinginan dan kebutuhan yang berbeda. Untuk itu pula Koperasi Persatuan Pedagang Kaki Lima Yogyakarta (KPPKLY) berusaha menciptakan sistem manajemen yang baik dan menciptakan situasi kerja yang nyaman bagi pekerjanya. Sehingga mampu memotivasi mereka untuk lebih meningkatkan kinerjanya. Berkaitan dengan hal tersebut maka perlu diperhatikan oleh para pengelolaan kegiatan usaha variabel-variabel yang mempunyai pengaruh terhadap motivasi pekerja. Penelitian ini dilakukan dengan tujuan utama mengetahui dan menganalisis pengaruh variabel-variabel: upah/gaji, tempat kerja, peralatan kerja, sikap pengusaha terhadap karyawan, sikap antar teman sejawat, kepercayaan dan tanggung jawab, kebutuhan untuk meningkatkan kemampuan dan kebutuhan berprestasi, terhadap motivasi kerja pada KPPKLY. Selanjutnya difokuskan pada teori isi untuk lebih memahami kebutuhan karyawan yang berbeda-beda, dan bagaimana cara untuk memenuhinya. Dalam teori isi ini, terdapat beberapa teori kebutuhan yang dikemukakan oleh para ahli ekonomi, diantaranya adalah Teori Abraham Moslow, Teori ERG Alderfer, Teori dua-faktor dari Frederick Herzberg dan Teori Kebutuhan Mc Clelland.

Berdasarkan pada latar belakang penelitian tersebut di atas, maka rumusan masalah penelitian adalah sebagai berikut: (1) Bagaimana motivasi kerja para pekerja, (2) Bagaimana penilaian pekerja terhadap variabel-variabel yang mempengaruhi motivasi kerjanya, (3) Apakah variabel-variabel yang mempengaruhi motivasi kerja para pekerja secara bersama-sama berpengaruh signifikan terhadap motivasi kerja para pekerja (4) Variabel manakah yang paling dominan berpengaruh terhadap motivasi kerja para pekerja

\section{KAJIAN TEORI}

Sesuai dengan uraian sebagaimana dikemukakan sebelumnya pada judul penelitian, latar belakang dan identifikasi serta rumusan masalah di atas, Untuk membatasi masalah agar tidak berkembang pada hal-hal diluar masalah, maka diberikan batasan masalah sebagai berikut: Objek penelitian adalah Persatuan Pedagang Kaki Lima Yogyakarta (PPKLY). Subjek penelitian adalah para pekerja pada Pedagang Kaki Lima Yogyakarta (PPKLY.

Motivasi kerja adalah kesediaan untuk mengeluarkan tingkat upaya yang tinggi ke arah tujuan organisasi, yang dikondisikan oleh kemampuan upaya itu untuk memenuhi sesuatu kebutuhan individual (Stephen P. Robbins: 2009). Sedangkan Gibson menyatakan Motivasi adalah konsep yang menguraikan tentang kekuatan-kekuatan yang ada dalam diri karyawan yang memulai dan mengarahkan perilaku. Selanjutnya batasan/difinisi yang dianut/ diimplementasikan dalam penelitian ini yaitu definisi/batasan yang diutarakan oleh (Stephen P. Robbins: 2009). Motivasi ialah kesediaan untuk mengeluarkan tingkat upaya yang tinggi ke arah tujuan organisasi, yang dikondisikan oleh kemampuan upaya itu untuk memenuhi sesuatu kebutuhan individual, adapun variabel-variabel yang mempengaruhi motivasi kerja meliputi: Upah/gaji, Tempat kerja, Peralatan kerja, Sikap pekerja terhadap pekerjaan, Sikap antar teman sejawat/kerja, Kepercayaan dan tanggung jawab, Kebutuhan untuk meningkatkan kemampuan, Kebutuhan untuk berprestasi. Hal tersebut diperkuat dengan Teori Hirarki Kebutuhan Maslow, Teori ERG Alderfer, Teori Dua Faktor Herzberg dan Teori Kebutuhan Mc Clelland, maka dalam penelitian ini akan dikaji tentang ke delapan variabel-variabel tersebut, ke delapan variabel-variabel 
dimaksud yaitu: (1) Upah, yaitu berupa imbalan terhadap pekerjaan yang dilakukan responden dalam bentuk satuan rupiah; (2) Tempat kerja, yaitu kondisi disekitar tempat karyawan bekerja yang meliputi penerangan, sirkulasi udara, temperatur, kebisingan, luas ruangan kerja, kebersihan dan kerapian; (3) Peralatan kerja, meliputi Kondisi dan kelengkapan peralatan kerja; (4) Sikap,dimaksud sikap pekerja terhadap pekerjaan dalam bekerja; (5) Sikap antar teman sejawat,dimaksud sikap sesama teman sekerja selama melakukan pekerjaan; (6) Kepercayaan dan tanggung jawab,dimaksud kepercayaan dan tanggung jawab yang diberikan pengurus kepada karyawan dalam menyelesaikan pekerjaan; (7) Kebutuhan untuk meningkatkan kemampuan, dimaksud kebutuhan untuk meningkat kan kemampuan yang berhubungan dengan pekerjaannya; (8) Kebutuhan untuk berprestasi,dimaksud kebutuhan untuk mencapai keberhasilan dari karyawan dalam melakukan pekerjaannya.

Manajemen Sumber Daya Manusia merupakan bagian dari manajemen umum yang memfokuskan pembahasannya pada unsur sumber daya manusia dan mempunyai tugas untuk mempelajari dan mengembangkan berbagai organisasi yang diperlukan oleh masyarakat. Beberapa definisi Manajemen Sumber Daya Manusia menurut para ahli : Manajemen Sumber Daya Manusia merupakan suatu istilah yang digunakan untuk menjelaskan ke aneka ragaman aktivitas-aktivitas yang terlibat dalam penarikan, pengembangan, dan mempertahankan tenaga kerja organisasional yang berbakat dan bersemangat. (J.Stoner.E, Freeman, and Gilbert JR: 1996). Manajemen Sumber Daya Manusia adalah pendayagunaan, pengembangan, penelitian, pemberian balas jasa dan pengelolaan individu anggota organisasi atau kelompok pekerja.( Henry Simamora:1999). Meskipun banyak ahli yang mendefinisikan manajemen sumber daya manusia, tetapi pada dasarnya memiliki arti yang sama yaitu manajemen yang menitik beratkan pada masalah ketenegakerjaan dalam organisasi tertentu. Proses manajemen sumber daya manusia adalah prosedur yang berlangsung terus menerus yang mencoba mempertahankan organisasi akan mendapat orang yang tepat diposisi yang tepat, pada saat dibutuhkan. Aktivitas-aktivitas dasar dari proses manajemen sumber daya manusia adalah: Perencanaan sumber daya manusia.

Didesain untuk memastikan bahwa personel yang diperlukan akan selalu terpenuhi secara memadai; Rekrutmen berkaitan dengan mengembangkan cadangan calon karyawan sejalan dengan rencana sumber daya manusia; Seleksi termasuk menggunakan formulir lamaran, daftar riwayat hidup, wawancara, pengujian keterampilan, dan mencocokkan informasi dari referensi untuk mengevaluasi dan menyaring calon karyawan bagi manajer, yang akhirnya akan memilih dan menerima calon; Sosialisasi (orientasi) didesain untuk membantu orang yang terpilih menyesuaikan diri dengan mulus kedalam organisasi; Pelatihan dan pengembangan keduanya bertujuan untuk meningkatkan kemampuan karyawan dalam memberikan kontribusi pada efektivitas organisasi. Pelatihan didesain untuk meningkatkan keterampilan dalam pekerjaan yang sekarang. Program pengembangan didesain untuk menyiapkan karyawan sebelum dipromosikan.; Penilaian prestasi kerja untuk membandingkan prestasi kerja seseorang dengan standar atau tujuan yang dikembangkan untuk posisi orang tersebut. Prestasi yang rendah mungkin menandakan perlunya tindakan korektif, seperti pelatihan tambahan, demosi, atau PHK, sedangkan prestasi yang tinggi mungkin menghasilkan penghargan, seperti kenaikan gaji, bonus, atau promosi.; Promosi, transfer, demosi, dan PHK mencerminkan nilai seorang karyawan bagi organisasi. Karyawan berprestasi tinggi dapat dipromosikan atau ditransfer 
untuk membantu mengembangkan keterampilan mereka, sedangkan karyawan berprestasi rendah mungkin didemosikan, ditransfer ke posisi yang kurang penting, atau bahkan PHK.

Motivasi dalam ilmu manajemen, khususnya pengelolaan perusahaan, motivasi merupakan salah satu topik penting yang harus dipahami oleh pimpinan dalam upaya mencapai tujuan perusahaan. Namun mendefinisikan motivasi, mengidentifikasi faktorfaktor yang mempengaruhinya, serta memahami proses bekerjanya, tetap merupakan sebuah fenomena yang sulit untuk diungkapkan dengan tuntas tanpa pemahaman yang integrative. Beberapa definisi motivasi yang dikemukakan oleh para ahli, diantaranya adalah: Motivasi kerja adalah kesediaan untuk mengeluarkan tingkat upaya yang tinggi ke arah tujuan organisasi, yang dikondisikan oleh kemampuan upaya itu untuk memenuhi sesuatu kebutuhan individual (Stephen P. Robbins:2009).

Motivasi adalah konsep yang menguraikan tentang kekuatan-kekuatan yang ada dalam diri karyawan yang memulai dan mengarahkan perilaku. (Gibson:1996) Agar perilaku karyawan sesuai dengan tujuan perusahaan maka harus ada perpaduan antara motivasi mereka dan permintaan organisasi (Reksodiprodjo dan Handoko:1986). Motivasi didefinisikan sebagai kesediaan untuk mengeluarkan tingkat upaya yang tinggi ke arah tujuan organisasi, yang dikondisikan oleh kemampuan upaya itu untuk memenuhi sesuatu kebutuhan individual (Stephen P. Robbins:2009). Motivasi yang ada pada seseorang akan mewujudkan suatu perilaku yang diarahkan pada tujuan mencapai sasaran kepuasan. Kebutuhan dan tujuan adalah merupakan konsep yang memberikan dasar untuk menyusun suatu pola dalam bekerja. Kebutuhan ialah kekurangan yang dirasakan seseorang pada suatu waktu tertentu. Tujuan ialah suatu hasil yang dicari karyawan yang dipandang sebagai kekuatan yang menarik orang untuk berperilaku dalam pencapaian tujuan yang diinginkan sehingga dapat mengurangi kebutuhan yang belum terpenuhi. Dalam penelitian ini ingin menganalisis variabel-variabel yang mempengaruhi kinerja. Secara konseptual dapat dijelaskan bahwa, kinerja yang merupakan hasil dari individu berupa prestasi yang telah diraih dipengaruhi oleh motivasi individu yang merupakan pendorong seseorang yang menimbulkan dan mengarahkan perilaku. Agar seseorang berperilaku sesuai dengan tujuannya didorong oleh kebutuhan. Kebutuhan merupakan kekurangan yang dialami individu pada suatu waktu tertentu. Kekurangan tersebut dapat bersifat fisik, yang oleh Maslow digolongkan menjadi lima hirarki, oleh Aldefer tiga perangkat kebutuhan yaitu eksistensi, keterkaitan, pertumbuhan, oleh Herzberg dikelompokkan dalam dua kondisi yaitu kondisi ekstrinsik dan kondisi intrinsik dan oleh Mc Clelland tiga teori kebutuhan yaitu kebutuhan berprestasi, kebutuhan berkuasa, kebutuhan berafiliasi. Proses motivasi sebagaimana diinterpretasikan oleh para ahli terarah kepada tujuan. Tujuan atau hasil yang dikejar oleh pekerja dipandang sebagai kekuatan-kekuatan yang menarik seseorang. Berdasarkan Teori Hirarki Kebutuhan Maslow, Teori ERG Alderfer, Teori Dua Faktor Herzberg dan Teori Kebutuhan Mc Clelland tersebut maka faktor-faktor yang mempengaruhi motivasi kerja pekerja organisasi adalah: (1) Upah berupa imbalan terhadap pekerjaan yang dilakukan responden dalam bentuk satuan rupiah; (2) Tempat kerja kondisi disekitar tempat karyawan bekerja yang meliputi penerangan, sirkulasi udara, temperatur, kebisingan, luas ruangan kerja, kebersihan dan kerapian; (3) Peralatan kerja Kondisi dan kelengkapan peralatan kerja; (4) Sikap pekerja terhadap pekerjaan bekerja; (5) Sikap antar teman sejawat sikap sesama teman sekerja selama melakukan pekerjaan; (6) Kepercayaan dan tanggung jawab kepercayaan dan tanggung jawab yang diberikan pengurus kepada karyawan dalam menyelesaikan pekerjaan; (7) Kebutuhan untuk meningkatkan kemampuan kebutuhan untuk meningkatkan kemampuan yang 
berhubungan dengan pekerjaannya; (8) Kebutuhan untuk berprestasi kebutuhan untuk mencapai keberhasilan dari karyawan dalam melakukan pekerjaannya.

Arah dan tujuan dari penelitian ini adalah untuk melihat bagaimana variabel-variabel yang terdiri dari upah, tempat kerja, peralatan kerja, sikap pekerja terhadap pekerjaan, sikap antar teman sejawat, kepercayaan dan tanggung jawab, kebutuhan untuk meningkatkan kemampuan, dan kebutuhan untuk berprestasi berpengaruh signifikan terhadap motivasi kerja. Dengan mengacu hal tersebut, maka diharapkan dapat menciptakan kondisi tertentu agar pekerja dapat lebih meningkatkan kinerjanya, sehingga tujuan kegiatan usaha dapat tercapai.

Berdasarkan kerangka pemikiran dan landasan teori-teori tersebut di atas, maka peneliti dapat memformulasikan kerangka penelitian sebagai berikut:


Gambar 1. Kerangka Penelitian

Sumber: Stephen P. Robbins, 2009 (modivikasi)

Hipotesis Penelitian. Berdasar kajian teori yang telah diuraikan di atas maka dan kerangka penelitian tersebut diatas, maka hipotesis adalah sebagai berikut:

H1 : Motivasi kerja para pekerja kuat.

H2 : Penilaian pekerja terhadap variabel-variabel yang mempengaruhi motivasi kerja pekerja signifikan.

H3 : Variabel-variabel yang terdiri dari upah, tempat kerja, peralatan kerja, sikap pekerja terhadap pekerjaan, sikap antar teman sejawat, kepercayaan dan tanggung jawab, kebutuhan untuk meningkatkan kemampuan, kebutuhan untuk berprestasi secara bersama-sama mempunyai pengaruh yang signifikan terhadap motivasi kerja karyawan.

H4 : Kebutuhan untuk berprestasi mempunyai pengaruh paling dominan terhadap motivasi kerja para pekerja. 


\section{METODE}

Bentuk penelitian yang digunakan adalah Penelitian Asosiatif. Penelitian asosiatif merupakan penelitian yang bertujuan untuk mengetahui pengaruh antara dua variabel atau lebih (Sugiyono: 1999). Dalam penelitian ini yang akan diteliti adalah delapan (8) variabel yang mempengaruhi motivasi kerja para pekerja.

Populasi adalah kelompok elemen yang lengkap, dimana kita tertarik untuk mempelajarinya atau menjadi objek penelitian (Kuncoro:2001). Populasi dalam penelitian ini adalah seluruh pekerja pada PPKLY berjumlah 74 karyawan. Dalam penelitian ini peneliti menggunakan teknik Sampling Sensus/sampel jenuh yaitu bila semua anggota populasi digunakan sebagai responden, mencakup keseluruhan populasi. Dengan taraf kesalahan sebesar $1 \%(\alpha=1 \%)$

Data yang digunakan dalam penelitian ini dapat dikelompokkan menjadi dua bagian yaitu: Data Primer, Data langsung dan segera dapat diperoleh dari sumber data, dalam hal ini dapat diperoleh langsung dari: Observasi, Interview, Kuesioner Data Sekunder,yaitu data yang diperoleh secara tidak langsung, dilaksanakan untuk melengkapi data primer serta dapat dipertanggung jawabkan. Variabel penelitian pada dasarnya merupakan sesuatu hal yang berbentuk apa saja yang ditetapkan oleh peneliti untuk dipelajari sehingga diperoleh informasi tentang hal tersebut, kemudian ditarik kesimpulannya. Variabel-variabel penelitian yang dimaksud adalah sebagai berikut:

a. Variabel Dependen (terikat). Variabel dependen disebut juga variabel terikat (Y) yaitu variabel yang dipengaruhi atau yang menjadi akibat, karena adanya variabel bebas. Dalam penelitian ini, yang merupakan variabel dependen adalah motivasi kerja (Y).

b. Variabel Independen (bebas). Variabel independen disebut juga variabel bebas (X) yaitu variabel yang mempengaruhi atau yang menjadi sebab perubahannya atau timbulnya variabel dependen (terikat). Dalam penelitian ini, yang menjadi variabel independen adalah upah (X1), tempat kerja (X2), peralatan kerja (X3), sikap pekerja terhadap pekerjaan (X4), sikap antar teman sejawat (X5), kepercayaan dan tanggung jawab (X6), kebutuhan untuk meningkatkan kemampuan (X7), dan kebutuhan berprestasi (X8).

Dalam penelitian ini, kuesioner dibagi dalam dua bagian. Bagian pertama berisi data tentang responden dan bagian kedua berisi tentang pertanyaan yang sifatnya tertutup dimana responden tinggal memilih jawaban yang telah disediakan oleh peneliti. Pertanyaan-pertanyaan itu mengenai variabel-variabel yang mempengaruhi motivasi kerja karyawan. Data yang diperoleh merupakan jawaban dari kuesioner yang telah dibagikan kepada karyawan. Data ini masih bersifat kualitatif, untuk itu data tersebut perlu dikuantitatifkan agar dapat menghasilkan data yang dapat dihitung. Skala penilaian yang digunakan adalah Skala Likert dengan lima kategori penilaian.

Uji Validitas, Reliabilitas dan Analisis Rata-Rata Hitung, digunakan untuk mengukur: Motivasi kerja karyawan secara keseluruhan, Penilaian karyawan terhadap variabelvariabel yang mempengaruhi motivasi kerja karyawan secara keseluruhan maupun per variabel. Kriteria motivasi kerja, berdasarkan pada interval sebagai berikut (Sudjana): Nilai jawaban: 1,00 - 1,79 = motivasi kerja sangat lemah; 1,80 - 2,59= motivasi kerja lemah; 2,60 - 3,39 = motivasi kerja sedang; 3,40 - 4,19 = motivasi kerja kuat; 4,20 - 5,00 $=$ motivasi kerja sangat kuat. Kriteria penilaian karyawan tersebut berdasarkan pada interval : dengan nilai jawaban : $1,00-1,79=$ penilaian karyawan sangat buruk; 1,80 $2,59=$ penilian karyawan buruk; $2,60-3,39=$ penilian karyawan cukup; $3,40-4,19=$ 
penilaian karyawan baik; 4,20 - 5,00 = penilaian karyawan sangat baik. Analisis Regresi Berganda analisis ini menggunakan Metode Analisis Stepwise, (program SPS) yang bertujuan untuk: (1). Mengetahui ada tidaknya pengaruh variabel-variabel seperti upah, tempat kerja, peralatan kerja, sikap manajemen terhadap karyawan, sikap antar teman sejawat, kepercayaan dan tanggung jawab, promosi, kebutuhan untuk meningkatkan kemampuan, kebutuhan untuk berprestasi terhadap motivasi karyawan. (2). Mengetahui variabel mana yang mempunyai pengaruh paling kuat terhadap motivasi karyawan.

Hasil analisis/hitung regresi ini kemudian diuji signifikansinya dengan menggunakan uji $\mathrm{F}$ Uji $\mathrm{F}$ digunakan untuk menguji atau membuktikan kebenaran hipotesis yang diajukan dalam penelitian ini yaitu bahwa variabel -variabel bebas diatas secara bersamasama berpengaruh terhadap motivasi kerja karyawan (variabel tergantung), jika F hitung > F tabel maka berarti hubungan tersebut adalah signifikan dan berlaku pula sebaliknya. Adjusted $\mathrm{R}^{2}$, diperlukan juga untuk menguji pengaruh masing-masing variabel bebas $\mathrm{X} 1$, $\mathrm{X} 2, \mathrm{X} 3, \mathrm{X} 4, \mathrm{X} 5, \mathrm{X} 6, \mathrm{X} 7, \mathrm{X} 8$, terhadap variabel tergantung $\mathrm{Y}$ dan untuk menetahui variabel mana yang paling berpengaruh. Untuk meng evaluasi model regresi yang terbaik peneliti menggunakan nilai Adjusted $\mathrm{R}^{2}$. Untuk $\mathrm{k}>1$ dan Ajusted $\mathrm{R}^{2}<\mathrm{R}^{2}$, bila jumlah variabel independen ditambah, maka Adjusted $\mathrm{R}^{2}$ naik dengan jumlah kenaikan kurang dari $\mathrm{R}^{2}$. Adjusted $\mathrm{R}^{2}$ dapat bernilai negatif kendati $\mathrm{R}^{2}$ selalu positif.

Bila Adjusted $\mathrm{R}^{2}$ bernilai negatif maka nilainya dianggap nol. Secara umum, bila tambahan variabel independen merupakan prediktor yang baik, maka akan menyebabkan nilai varians naik, dan pada gilirannya Adjusted $\mathrm{R}^{2}$ meningkat. Sebaliknya, bila tambahan variabel baru tidak meningkatkan varians, maka Adjusted $\mathrm{R}^{2}$ akan menurun. Artinya, tambahan variabel baru tersebut bukan merupakan prtediktor yang baik bagi variabel dependen.

\section{HASIL DAN PEMBAHASAN}

Analisis data dalam penelitian ini bertujuan untuk menjawab pertanyaan penelitian dan untuk mencapai tujuan penelitian seperti yang telah diuraikan didepan. Data diperoleh dari kuesioner kemudian dikuantitatifkan agar dapat dianalisis secara statistik. Pertanyaan yang digunakan dalam kuesioner terdiri dari dua bagian, yaitu: (1) Bagian I berisi data tentang responden; (2) Bagian II berisi tentang: (a) Motivasi (Y); (b) Upah (X1); (c) Tempat kerja (X2); (d) Peralatan kerja (X3); (e) Sikap pekerja terhadap pekerjaan (X4); (f) Sikap antar teman sejawat (X5); (g) Kepercayaan dan tanggung jawab (X6); (h) Kebutuhan untuk meningkatkan kemampuan (X7); (i) Kebutuhan untuk berprestasi (X8)

Sebelum mengadakan penelitian yang sesungguhnya, telah diadakan suatu uji coba kuesioner kepada sejumlah 30 orang dengan tujuan untuk mengetahui kesesuaian kuesioner yang digunakan sebagai alat ukur dengan tujuan yang akan diukur serta untuk mengetahui pengukuran yang dilakukan relative konsisten atau tidak.

Uji Validitas Dan Reliabilitas. Validitas, Untuk mengetahui valid/sahih tidaknya kuesioner akan dibandingkan $r$ hitung dengan nilai $r$ tabel pada taraf signifikansi $\alpha=0,01$. Jika $\mathrm{r}$ hitung $>\mathrm{r}$ tabel maka pengukuran dapat dikatakan valid/sahih. 
Tabel 2. Hasil Uji Validitas

\begin{tabular}{|c|c|c|c|c|}
\hline Faktor & Butir No & $\mathrm{R}$ hitung & $\mathrm{R}$ tabel & Status \\
\hline \multirow[t]{5}{*}{ Motivasi } & 1 & 0.574 & 0.423 & Sahih \\
\hline & 2 & 0.476 & 0.423 & Sahih \\
\hline & 3 & 0.458 & 0.423 & Sahih \\
\hline & 4 & 0.557 & 0.423 & Sahih \\
\hline & 5 & 0.558 & 0.423 & Sahih \\
\hline \multirow[t]{5}{*}{ Upah } & 6 & 0.574 & 0.423 & Sahih \\
\hline & 7 & 0.764 & 0.423 & Sahih \\
\hline & 8 & 0.549 & 0.423 & Sahih \\
\hline & 9 & 0.564 & 0.423 & Sahih \\
\hline & 10 & 0.463 & 0.423 & Sahih \\
\hline \multirow{5}{*}{ Tempat kerja } & 11 & 0.534 & 0.423 & Sahih \\
\hline & 12 & 0.577 & 0.423 & Sahih \\
\hline & 13 & 0.650 & 0.423 & Sahih \\
\hline & 14 & 0.467 & 0.423 & Sahih \\
\hline & 15 & 0.550 & 0.423 & Sahih \\
\hline \multirow{5}{*}{ Peralatan kerja } & 16 & 0.676 & 0.423 & Sahih \\
\hline & 17 & 0.625 & 0.423 & Sahih \\
\hline & 18 & 0.459 & 0.423 & Sahih \\
\hline & 19 & 0.493 & 0.423 & Sahih \\
\hline & 20 & 0.682 & 0.423 & Sahih \\
\hline \multirow{5}{*}{$\begin{array}{l}\text { Sikap pekerja terhadap } \\
\text { pekerjaan }\end{array}$} & 21 & 0.657 & 0.423 & Sahih \\
\hline & 22 & 0.752 & 0.423 & Sahih \\
\hline & 23 & 0.613 & 0.423 & Sahih \\
\hline & 24 & 0.622 & 0.423 & Sahih \\
\hline & 25 & 0.695 & 0.423 & Sahih \\
\hline \multirow{5}{*}{$\begin{array}{c}\text { Sikap antar teman } \\
\text { sejawat }\end{array}$} & 26 & 0.524 & 0.423 & Sahih \\
\hline & 27 & 0.749 & 0.423 & Sahih \\
\hline & 28 & 0.613 & 0.423 & Sahih \\
\hline & 29 & 0.665 & 0.423 & Sahih \\
\hline & 30 & 0.618 & 0.423 & Sahih \\
\hline \multirow{5}{*}{$\begin{array}{c}\text { Kepercayaan dan } \\
\text { tanggung jawab }\end{array}$} & 31 & 0.836 & 0.423 & Sahih \\
\hline & 32 & 0.704 & 0.423 & Sahih \\
\hline & 33 & 0.761 & 0.423 & Sahih \\
\hline & 34 & 0.581 & 0.423 & Sahih \\
\hline & 35 & 0.746 & 0.423 & Sahih \\
\hline Kebutuhan & 36 & 0.610 & 0.423 & Sahih \\
\hline meningkatkan & 37 & 0.781 & 0.423 & Sahih \\
\hline \multirow[t]{3}{*}{ kemampuan } & 38 & 0.742 & 0.423 & Sahih \\
\hline & 39 & 0.610 & 0.423 & Sahih \\
\hline & 40 & 0.459 & 0.423 & Sahih \\
\hline \multirow[t]{5}{*}{ Kebutuhan berprestasi } & 41 & 0.680 & 0.423 & Sahih \\
\hline & 42 & 0.624 & 0.423 & Sahih \\
\hline & 43 & 0.506 & 0.423 & Sahih \\
\hline & 44 & 0.497 & 0.423 & Sahih \\
\hline & 50 & 0.715 & 0.423 & Sahih \\
\hline
\end{tabular}

Sumber: data primer diolah

Hasil uji validitas dapat dilihat pada tabel diatas. Dari hasil pengujian validitas tersebut terlihat bahwa dari semua butir yang ada memiliki nilai $r$ hitung yang lebih besar 
dari nilai $r$ tabel, sehingga instrument yang digunakan mampu menjalankan fungsi ukurnya atau memberikan hasil ukur yang sesuai dengan maksud dilakukannya pengukuran tersebut. Sehingga dapat disimpulkan bahwa seluruh butir tersebut adalah valid/sahih.

Reliabilitas, Untuk mengukur reliabilitas digunakan Alpha Cronbach yaitu mengukur keandalan butir-butir dalam suatu faktor, maka digunakan taraf signifikansi 1\% (0.01). Jika $r$ hitung > r tabel maka hipotesis dikatakan reliabel.

Tabel 3. Hasil Uji Reliabitas Terhadap Variabel yang Diteliti

\begin{tabular}{lc}
\hline \multicolumn{1}{c}{ Variabel } & Koefisien Alpha \\
\hline Motivasi & 0.740 \\
Upah & 0.795 \\
Tempat kerja & 0.755 \\
Peralatan kerja & 0.797 \\
Sikap pekerja terhadap p[ekerjaan & 0.842 \\
Sikap antar teman sejawat & 0.824 \\
Kepercayaan dan tanggung jawab & 0.884 \\
Kebutuhan meningkatkan kemampuan & 0.831 \\
Kebutuhan berprestasi & 0.810 \\
\hline
\end{tabular}

Sumber: data primer diolah

Dari pengujian terhadap 8 variabel, menunjukkan bahwa data yang diperoleh dalam penelitian ini dapat diandalkan (reliabel), dimana nilai Koefisien Alpha (rtt) lebih besar dari $\mathrm{r}$ tabel dengan taraf signifikansi sama yaitu sebesar $1 \%$ dan $\mathrm{db}=\mathrm{N}-2$ atau $\mathrm{db}=30-2=$ 28 maka diperoleh nilai $r$ tabel sebesar 0.423 .

Karakteristik Responden, Analisis ini digunakan untuk melihat karakteristik atau profil dari responden. Dari hasil kuesioner yang diedarkan pada responden, data yang dapat diklasifikasikan dalamtabel sebagai berikut:

Tabel 4. Karakteristik Responden Berdasarkan Jenis Kelamin

\begin{tabular}{lcc}
\hline Keterangan & Jumlah & Persentase \\
\hline Wanita & 48 & 64.9 \\
Pria & 26 & 35.1 \\
TOTAL & 74 & 100.0 \\
\hline
\end{tabular}

Sumber: data primer diolah

Berdasarkan Tabel tersebut dari 74 karyawan, 48 orang atau $64.9 \%$ diantaranya adalah wanita dan 26 orang atau $35.1 \%$ adalah pria. Jadi dapat disimpulkan bahwa sebagian besar pekerja adalah wanita.

Tabel 5. Karakteristik Responden Berdasarkan Pendidikan Terakhir

\begin{tabular}{ccc}
\hline Keterangan & jumlah & Persentase \\
\hline Kurang dari atau sama dengan SLTP atau sederajat & 40 & 54.1 \\
SLTA & 19 & 25.7 \\
D1-D3 & 15 & 20.3 \\
TOTAL & 74 & 100.0 \\
\hline
\end{tabular}

Sumber: data lapangan diolah 
Berdasarkan Tabel tersebut dari 74 karyawan 40 orang atau $54.1 \%$ diantaranya berpendidikan terakhirnya adalah kurang dari atau sama dengan SLTP atau sederajat, 19 orang atau $25.7 \%$ diantaranya pendidikan terakhirnya adalah SLTA dan 15 orang atau 20.3\% diantaranya pendidikan terakhirnya adalah D1 - D3.

Tabel 6. Karakteristik Responden Berdasarkan Usia

\begin{tabular}{ccc}
\hline Keterangan & Jumlah & Persentase \\
\hline $20-25$ tahun & 20 & 27.03 \\
$26-35$ tahun & 26 & 35.14 \\
$36-45$ tahun & 18 & 24.32 \\
Lebih dari 45 tahun & 10 & 13.51 \\
TOTAL & 74 & 100.0 \\
\hline
\end{tabular}

Sumber: data lapangan diolah

Berdasarkan tabel tersebut terlihat bahwa responden terbanyak yaitu sebesar 26 (35.14\%) berusia diantara 26 - 35 tahun, kemudian disusul $20(27.03 \%)$ berusia $20-25$ tahun, kemudian 18 (24.32\%) berusia diantara 36 - 45 tahun, dan kemudian 10 (13.51\%) berusia lebih dari 45 tahun

Tabel 7. Karakteristik Responden Berdasarkan Masa Kerja

\begin{tabular}{ccc}
\hline Keterangan & Jumlah & Persentase \\
\hline $0-5$ tahun & 40 & 54.05 \\
$6-10$ tahun & 26 & 35,14 \\
Lebih dari 10 tahun & 8 & 10,81 \\
TOTAL & 74 & 100.0 \\
\hline
\end{tabular}

Sumber: data primer diolah

Berdasarkan tabel tersebut terlihat bahwa jumlah responden terbanyak yaitu sebesar $40(54.05 \%)$ memiliki masa kerja lebih dari 0-5 tahun, kemudian disusul $26(35,14 \%)$ memiliki masa kerja 6 - 10 tahun, kemudian disusul 8 (10.18\%) memiliki masa kerja lebih 10 tahun.

Analisis Motivasi Kerja Karyawan, Metode ini digunakan untuk mengetahui motivasi kerja karyawan secara keseluruhan dengan menggunakan metode rata-rata hitung, dimana sebelumnya responden diminta untuk memilih alternative jawaban terhadap pernyataanpernyataan yang menunjukkan motivasi kerja karyawan. Setelah terkumpul data dari responden dilakukan perhitungan frekuensi responden yang menjawab sangat setuju, setuju, netral, tidak setuju, dan sangat tidak setuju. Setelah frekuensi responden pada masing-masing jawaban diketahui nilai rata-rata hitung dinyatakan dalam tabel sebagai berikut:

Tabel 8. Hasil Perhitungan Rata-Rata Hitung

\begin{tabular}{lcc}
\hline \multicolumn{1}{c}{ Variabel } & Mean & Kriteria \\
\hline Upah & 3.7784 & Baik \\
Tempat kerja & 3.8595 & Baik \\
Peralatan kerja & 3.7081 & Baik \\
Sikap manajemen terhadap karyawan & 3.8270 & Baik \\
Sikap antar teman sejawat & 3.8514 & Baik \\
\hline
\end{tabular}




\begin{tabular}{lcc}
\hline \multicolumn{1}{c}{ Variabel } & Mean & Kriteria \\
\hline Kepercayaan dan tanggung jawab & 3.7865 & Baik \\
Promosi & 3.9054 & Baik \\
Kebutuhan untuk meningkatkan kemampuan & 3.9270 & Baik \\
Kebutuhan untuk berprestasi & 3.7027 & Baik \\
\hline
\end{tabular}

Sumber: data primer diolah

Dari perhitungan menggunakan metode rata-rata hitung diperoleh kesimpulan bahwa penilaian karyawan terhadap variabel-variabel yang mempengaruhi motivasi kerja pekerja adalah baik, karena berada pada interval $3.40-4.19$.

Pengaruh Variabel-Variabel Yang Mempengaruhi Motivasi Kerja Karyawan. Analisis ini digunakan untuk mengetahui ada tidaknya pengaruh variabel-variabel independen (yaitu variabel upah, tempat kerja, peralatan kerja, sikap pekerja terhadap pekerjaan, sikap antar teman sejawat, kepercayaan dan tanggung jawab, promosi, kebutuhan untuk meningkatkan kemampuan, dan kebutuhan untuk berprestasi) terhadap variabel dependen (motivasi kerja). Dalam analisis ini penulis menggunakan analisis regresi berganda dengan Metode Stepwise. Dengan menggunakan Metode Analisis Stepwise dapat dilihat bahwa hanya terdapat dua variabel independen yang berpengaruh signifikan terhadap variabel dependen, yaitu variabel kebutuhan untuk berprestasi, variabel sikap pekerja terhadap pekerjaan. Ketiga variabel independen tersebut mempengaruhi variabel dependen sebesar 0.668 atau $66.8 \%$ yang dapat dilihat dari besarnya angka Adjusted R Square. Berarti variabel independen mempengaruhi variabel dependen sebesar $66.8 \%$, sedangkan sisanya sebesar 33.2\% dipengaruhi oleh faktor-faktor lain. Untuk menguji atau untuk membuktikan bahwa variabel independen secara serentak atau bersama-sama berpengaruh terhadap variabel dependen (motivasi kerja) digunakan uji F. Uji $\mathrm{F}$ dilakukan dengan membandingkan $\mathrm{F}$ hitung dengan $\mathrm{F}$ tabel pada taraf nyata $\alpha$ $=0.01$. Dengan derajat bebas $\mathrm{n}-1-\mathrm{k}=74-1-3=70$, tingkat signifikansi $1 \%$, diperoleh $\mathrm{F}$ tabel sebesar 2.67. Dan hasil perhitungan data dengan menggunakan komputer dapat dilihat bahwa $\mathrm{F}$ hitung sebesar 50.022 lebih besar dari $\mathrm{F}$ tabel sebesar 2.67, atau bisa dilihat dari tingkat signif $F=0.000$. Hal ini berarti variabel-variabel tersebut secara bersama-sama berpengaruh terhadap motivasi kerja karyawan.

Analisis Variabel Yang Memiliki Pengaruh Paling Dominan Terhadap Motivasi Kerja Karyawan. Untuk mengetahui variabel mana yang mempunyai pengaruh paling dominan terhadap motivasi kerja karyawan maka dapat dilihat melalui besarnya nilai Adjusted $\mathrm{R}^{2}$. Nilai Adjusted $\mathrm{R}^{2}$ masing-masing variabel yang mempengaruhi motivasi kerja karyawan adalah seperti pada Tabel 9.

Dari ke delapan variabel-variabel yang mempengaruhi motivasi kerja karyawan, yang memiliki nilai Ajusted $\mathrm{R}^{2}$ yang paling besar adalah variabel kebutuhan untuk berprestasi (X.8) yaitu sebesar $47.7 \%$. Sehingga dapat dikatakan bahwa variabel kebutuhan untuk berprestasi (X.8) mempunyai pengaruh yang paling dominan terhadap motivasi kerja para pekerja. 
Tabel 9. Hasil Nilai Adjusted $\mathrm{R}^{2}$

\begin{tabular}{lc}
\hline \multicolumn{1}{c}{ Variabel } & Ajusted $\mathrm{R}^{2}$ \\
\hline Upah (X.1) & $23.6 \%$ \\
Tempat kerja (X.2) & $5.1 \%$ \\
Peralatan kerja (X.3) & $25.5 \%$ \\
Sikap manajemen terhadap karyawan & $40 \%$ \\
(X.4) & \\
Sikap antar teman sejawat (X.5) & $5.8 \%$ \\
Kepercayaan dan tanggung jawab (X.6) & $1.3 \%$ \\
Kebutuhan meningkatkan kemampuan & $-0.9 \%$ \\
(X.7) & \\
Kebutuhan untuk berprestasi (X.8) & $47.7 \%$ \\
\hline
\end{tabular}

Sumber: dataprimer diolah

\section{PENUTUP}

Simpulan. Pertama. Motivasi kerja pekerja pada KPPKLY adalah kuat. Dikatakan kuat karena dari hasil perhitungan dengan menggunakan metode analisis rata-rata hitung diperoleh hasil sebesar 3.8432. berada pada interval antara 3.40 - 4.19. Hal ini berarti hipotesis satu, motivasi kerja pekerja pada KPPKLY kuat terbukti/diterima. Kedua. Penilaian pekerja pada KPPKLY terhadap variabel-variabel yang mempengaruhi motivasi kerja pekerja secara keseluruhan adalah baik. Dikatakan baik karena dari hasil perhitungan dengan menggunakan metode analisis rata-rata hitung diperoleh hasil sebagai berikut: upah $=3.778$, tempat kerja $=3.8595$, peralatan kerja $=3.7081$, sikap pekerja terhadap pekerjaan $=3.8270$, sikap antar teman sejawat $=3.8514$, kepercayaan dan tanggung jawab $=3.7865$, kebutuhan untuk meningkatkan kemampuan $=3.9270$ dan kebutuhan untuk berprestasi $=3.7027$, berada pada interval antara $3.40-4.19$. Hal ini berarti hipotesis dua, penilaian karyawan terhadap variabel-variabel yang mempengaruhi motivasi kerja pekerja baik terbukti/diterima. Ketiga. Terdapat pengaruh antara variabelvariabel independen yang terdiri dari variabel kebutuhan untuk berprestasi, variabel sikap pekerja terhadap pekerjaan. Hal ini dapat dilihat dari besarnya Adjusted R square, yaitu 0.668 atau $66.8 \%$. Berarti $66.8 \%$ motivasi kerja karyawan dipengaruhi oleh ke dua variabel tersebut, sedangkan sisanya $29.6 \%$ dipengaruhi oleh variabel lain yang tidak masuk dalam model penelitian. Variabel-variabel tersebut secara bersama-sama mempengaruhi motivasi kerja, hal ini dapat diketahui dengan membandingkan $\mathrm{F}$ hitung dengan F tabel. Dari perhitungan diperoleh F hitung sebesar 50.022 lebih besar dari $\mathrm{F}$ tabel sebesar 2.67. Keempat. Kebutuhan untuk berprestasi mempunyai pengaruh yang paling dominan terhadap motivasi kerja pada pekerja pada KPPKLY. Hal ini dapat dilihat dengan menggunakan Adjusted $\mathrm{R}^{2}$. Hasil Dari perhitungan Adjusted $\mathrm{R}^{2}$ diperoleh hasil sebagai berikut $:$ upah $=23.6 \%$, tempat kerja $=5.1 \%$, peralatan kerja $=25.5 \%$, sikap pekerja terhadap pekerjaan $=40 \%$, sikap antar teman sejawat $=5.8 \%$, kepercayaan dan tanggung jawab $=1.3 \%$, kebutuhan untuk meningkatkan kemampuan $=0.9 \%$, kebutuhan untuk berprestasi $=47.7 \%$. Dari hasil perhitungan diatas dapat diketahui bahwa kebutuhan untuk berprestasi memiliki pengaruh yang paling besar atau paling kuat. Hal ini berarti hipotesis empat, kebutuhan untuk berprestasi mempunyai pengaruh dominan terhadap motivasi kerja pada terbukti/diterima. 
Saran. Berdasarkan dari hasil penelitian dan analisis data yang telah dikemukakan seperti di atas, maka saran Pertama, Motivasi kerja karyawan sangat diperlukan untuk kemajuan suatu kegiatan usaha. Karena itulah pengetahuan tentang motivasi perlu diketahui oleh setiap pekerja dan pengelola usaha diharapkan dapat mengembangkan tanggung jawab bersama untuk mencapai tujuan kegiatan usaha sehingga setiap pekerja dapat menyumbangkan sesuai dengan kepentingan dan kemampuan mereka. Kedua. Kebutuhan untuk meningkatkan kemampuan, dan kebutuhan untuk berprestasi sangat berpengaruh terhadap motivasi kerja para pekerja. Untuk itu para pengelola usaha diharapkan selalu memperhatikan variabel tersebut, sehingga dapat meningkatkan kinerja karyawan dan tujuan perusahaan dapat tercapai dengan baik. Ketiga. Pengaruh antara variabel independen dengan variabel dependen. Untuk itu pengelola usaha diharapkan selalu memperhatikan variabel-variabel yang mempengaruhi motivasi kerja karyawan yang meliputi upah, tempat kerja, peralatan kerja, sikap manajemen terhadap karyawan, sikap antar teman sejawat, kepercayaan dan tanggung jawab, kebutuhan untuk meningkatkan kemampuan, dan kebutuhan untuk berprestasi, ke delapan variabel tersebut merupakan satu kesatuan yang saling berhubungan dan saling berpengaruh. Keempat. Pengaruh paling dominan terhadap motivasi kerja pekerja, dapat adalah variabel kebutuhan untuk berprestasi memiliki pengaruh yang paling signifikan. Untuk itu diharapkan pengelola usaha harus terus memberikan kesempatan karyawan untuk lebih maju, memberikan kebebasan kepada pekerja untuk berprestasi mengeluarkan ide dan gagasan-gagasannya. Dan memberikan sarana dan prasarana untuk pengembangan pekerja, antara lain pelatihan/kursus-kursus. Para pengelola usaha tidak boleh mengabaikannya dan harus tetap memperhatikannya, agar kinerja para pekerja dapat meningkat secara terus-menerus sehingga kegiatan usaha mempunyai keberlanjutan yang terjamin.

Implikasi Manajerial. Variabel kebutuhan untuk berprestasi (X.8) paling signifikan pengaruhnya, Untuk itu para pengelola usaha tidak boleh mengabaikannya dan harus tetap memperhatikannya, agar kinerja para pekerja dapat meningkat secara terus-menerus sehingga kegiatan usaha mempunyai keberlanjutan yang terjamin, di samping itu variabel variabel: upah (X.1), tempat kerja (X.2), peralatan kerja (X.3), sikap pekerja terhadap pekerjaannya (X.4), sikap antar teman sejawat (X.5), kepercayaan dan tanggung jawab (X.6), kebutuhan untuk meningkatkan kemampuan (X.7), harus tetap diperhatikan karena saling berkaitan dan berhubungan. Jika variabel-variabel tersebut diabaikan oleh para pengelola usaha, maka Turn Over SDM akan menjadi tinggi, yang artinya stabilitas keberlanjutan kegiatan usaha akan terganggu.

\section{DAFTAR RUJUKAN}

Arief Subiyantoro, Khoirul Hikmah, (2014) “KUD Members'Participation Development though Society Education", European Jurnal of Business and Management, 6 (38).

Boge Triatmanto, Sunardi, (2001) “Analisis Variabel-variabel Yang Mempengaruhi Motivasi Kerja Karyawan Pada Hotel Berbintang Di Kabupaten Dan Kodya Malang", Jurnal Ekonomi dan Bisnis, VII (02) September.

Bilson Simamora, (2017) "Antisipasi Emosi Orang LainSebagai Determinan Motivasi Berbasis Kompetensi: Sebuah Kerangka Konseptual", Jurnal Manajemen Kwik Kian Gie Scool of Business, 4 (1) November. 
Donnely, R, Donnely Mel Gibson John Ivancevich, (1997) Organizatioanal Behavior Structure Prosses. Michigan: Timer Higer Education Group.

Gibson, James L, John M, Ivancevich, and James H. Donnely, (1996) Organisasi dan Manajemen, Terjemahan, Edisi Empat, Erlangga, Jakarta.

George \& Jennifer M. Jones, Gareth R. (1996) Understanding and Managing Organizational Behavior. USA: Addison- Wesley Publishing Company Inc.

Harry Simamora, (1999) Manajemen Sumber Daya Manusia, Penerbit YKPN, Yogyakarta.

J. Stoner, E.Freeman, and Gilbert JR, 1996, Manajemen, Edisi Bahasa Indonesia, Jilid 2, Prentice-Hall Inc.

Jajat Kristanto, (2016) "Diagram ProsesKebutuhan -Kepuasan Konsumen", Journal or Management Studies Presiden Univercity, 1(1) Maret

Kelly, George, (1992) The Kognitif perpective in personality theory, dikutip langsung oleh Larry A Helle \& Daniel J. Zieger, Personality Theories - Basic Assumptions, Research and Application. New York: McGraw_Hill, Inc.

Mudrajad Kuncoro, (2003) Metode Riset Untuk Bisnis dan Ekonomi, Erlangga, Jakarta.

Paul Hersey and Kenneth H Blanchard, (1988) Management of Organizational Behavior Utilizing Human Resources Singapore Prentice- Hall,Inc.

Reksohadiprodjo, Sukanto dan T. Hani Handoko, (1986) Organisasi Perusahaan, Edisi Kedua, Cetakan Pertama, Penerbit BPFE UGM, Yogyakarta.

Stephen P Robbin,. (2009) Organizational Behavior. New Jersey. Prentice Hall Sugiyono, (1999) Metodologi Penelitian Bisnis, CV Alfabeta, Bandung.

Sugiyono, (2002) Metode Penelitian Bisnis, Alfabeta, Bandung.

Sutrisno Hadi, (2000) Seri program statistik versi 2000 Universitas Gadjah Mada, Yogyakarta.

Suwarto, F.X., (2009) "Peran Manajer Dalam Perencanaan Korporat (Corporate Plan), Melalui pendekatan TeknikAnalisis Lingkungan Usaha," Jurnal Manajemen FE UNTAR, XIII (02), Juni.

Suwarto F.X., (2010) "Pengaruh Kemampuan Interpersonal danKedewasaan Emosional Terhadap Daya Usaha Manajer," Jurnal Manajemen FE UNTAR, XIV (01), Februari .

Suwarto F.X., (2015) "Pengaruh Budaya Organisasi dan Pengembangan Karier Terhadap Kepuasan Kerja Serta Dampaknya Terhadap Kinerja Karyawan", Jurnal Manajemen FE UNTAR, XIX (02), Juni.

Suwarto F.X., (2016) "Hubungan Antara Ketahanan FisikMentalSpiritual dan Kemampuan Mengelola Stres Serta Tingkat Kepercayaan Diri Dengan Motivasi Kerja", Jurnal Manajemen FE UNTAR, XX (02), Juni.

Suwarto F.X.,Arief Subyantoro.,Haddy Suprapto., (2016) "Analysis of Causal Relational Model Between Organizational Commitment", International Journal of Management Sciences, 7 (4). 